\title{
Runx3 is a key modulator during the epithelial-mesenchymal transition of alveolar type II cells in animal models of BPD
}

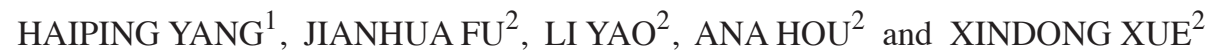 \\ ${ }^{1}$ Department of Pediatrics, Cangzhou Central Hospital, Cangzhou, Hebei 061000; ${ }^{2}$ Department of Pediatrics, \\ Shengjing Hospital of China Medical University, Shenyang, Liaoning 110004, P.R. China
}

Received November 1, 2016; Accepted August 31, 2017

DOI: 10.3892/ijmm.2017.3135

\begin{abstract}
Bronchopulmonary dysplasia (BPD) is a major challenge for premature infants; however, the underlying mechanisms remain unclear. We previously reported that epithelial-mesenchymal transition (EMT) in alveolar type II (AT2) epithelial cells influences the normal alveolar development process. In this study, we wished to examine whether Runx3 is an important factor for BPD by regulating EMT in AT2 cells. In vivo, animal models of BPD were established by placing newborn rats in hyperoxia tanks. Lung tissue and isolated AT2 cells were collected on different days following exposure to oxygen. The pathological changes in lung tissue, alveolar development and Runx3 expression were then investigated. In vitro, RLE-6TN cells were divided into 5 groups as follows: the control, Runx 3 , siRunx 3 , transforming growth factor- $\beta 1$ (TGF- $\beta 1$ ) and Runx 3 + TGF- $\beta 1$ groups, and the biomarkers of EMT were investigated. In the newborn rat model of BPD, Runx3 protein and mRNA levels in both lung tissue and BPD-derived AT2 cells were significantly lower than those in the control group. The correlation between Runx3 protein expression and pulmonary development indicators was analyzed; Runx 3 expression positively correlated with the radial alveolar count (RAC) and the percentage of smooth muscle actin-positive secondary septa, but negatively correlated with alveolar wall thickness. EMT was observed in the RLE-6TN cells in which the Runx3 gene was knocked down and follwoing TGF- $\beta 1$-induced EMT stimulation; however, TGF- $\beta 1$ failed to induce EMT in the RLE-6TN cells overexpressing Runx3. On the whole, our data indicte that low Runx3 levels may promote
\end{abstract}

Correspondence to: Dr Jianhua Fu, Department of Pediatrics, Shengjing Hospital of China Medical University, 36 Sanhao Street, Heping, Shenyang, Liaoning 110004, P.R. China

E-mail: jianhuafu1965 @126.com

Abbreviations: BPD, bronchopulmonary dysplasia; EMT, epithelial-mesenchymal transition; AT2 cells, alveolar type II epithelial cells; RAC, radial alveolar count; $\alpha$-SMA, $\alpha$-smooth muscle actin; CLD, chronic lung disease; AT1 cells, alveolar type I epithelial cells; SPC, surfactant protein C; E-cad, E-cadherin; N-cad, N-cadherin; TEM, transmission electron microscope

Key words: Runx3, bronchopulmonary dysplasia, alveolar type II cells, epithelial-mesenchymal transition, newborn rats
EMT, while high Runx3 levels inhibit TGF- $\beta 1$-induced EMT. Therefore, we predict that low levels of Runx3 in BPD lung tissue may promote EMT in AT2 cells, thus affecting alveolar development.

\section{Introduction}

Bronchopulmonary dysplasia (BPD), also known as chronic lung disease (CLD), occurs primarily in premature infants. BPD has a higher morbidity in premature infants with a lower birth weight and fetal age (1). In premature infants with a birth weight $<1,250 \mathrm{~g}$, almost $97 \%$ also present with BPD (2). The major pathological changes associated with BPD are alveolar simplification, abnormal angiogenesis and various degrees of pulmonary fibrosis (3), which result from both injury and repair mechanisms. Alveolar simplification directly influences the effective alveolar ventilation area, as well as respiratory function. Alveolar type II (AT2) epithelial cells play an important role in the formation of alveoli during pulmonary development. AT2 cells can differentiate into alveolar type I (AT1) epithelial cells and can promote the formation of alveolar structure and the air-blood barrier, promoting normal alveolar development (4). During the normal repair process that occurs in response to pulmonary epithelial injury, AT2 cells differentiate into AT1 cells and proliferate to rebuild the air-blood barrier (5). The normal differentiation of AT2 cells into AT1 cells is essential for normal alveolar development and repair function. Previously (6), we provided evidence of epithelial-mesenchymal transition (EMT) in AT2 cells isolated from rat lung tissue from BPD model systems; we hypothesized that the development of EMT may influence both normal development, as well as the repair processes of alveoli. However, the mechanisms by which EMT occurs in BPD remain poorly understood. In this study, we explored the factors which regulate the development of EMT in AT2 cells in the context of BPD.

Runx 3 is a runt domain transcription factor; its expression is closely associated with several diseases and is also a key regulator of gene expression during lung vasculogenesis (7-9). The majority of recent studies on Runx3 have focused on the role of the transcription factor in cancer metastasis; these studies have found that low levels of Runx3 can promote EMT (10), contribute to cancer metastasis (11) and can even be used as an early predictor of cancer development (12). Increased Runx3 expression in cancer cells may inhibit the production of cancer 
stem cells and reduce the occurrence of tumors (13). In addition, Runx3 exhibits a spatiotemporal expression during embryonic development (14) and also plays a role in pulmonary development. Lee et al (15) studied lung tissue from Runx $3^{-/-}$mice. They found that, compared with wild-type mice, Run $\times 3^{-/}$mice exhibited abnormal alveolar remodeling and alveolar dysplasia 1 day after birth; in addition, they observed the co-expression of surfactant protein B (SPB), an alveolar epithelial marker and Clara cell $10 \mathrm{kDa}$ protein $(\mathrm{CC} 10)$, a bronchiolar epithelial marker in the bronchiolar epithelial cells of Runx $3^{-/-}$mice, indicating the decreased differentiation of epithelial cells. Recently, Lee et al (16) confirmed the presence of abnormal EMT in the lungs of Runx $3^{-/-}$mice.

BPD is a result of the disruption of the normal pulmonary development process; Runx3 is an important factor in such a process and can affect EMT. Our previous study (6) confirmed the presence of EMT in lung tissues of newborn rats with BPD. In this study, we wished to determine whether the decreased expression of Runx3 in BPD-affected lung tissue promotes EMT in AT2 cells, and may thus influence the normal pulmonary development process and contribute to the occurrence of BPD. Therefore, we measured Runx 3 expression in lung tissues and isolated AT2 cells from the tissue of rats with BPD, and observed the effects of abnormal Runx3 expression on the occurrence of EMT in the RLE-6TN cell line in vitro. We also analyzed the correlation between Runx 3 protein expression in lung tissues and pulmonary development indicators in vivo.

\section{Materials and methods}

Animal models and lung tissue preparation. Animal models of BMD were established as previously described (17). Pregnant Wistar rats with a body weight of 200-220 g were purchased from the Experimental Animal Center of China Medical University. Each pregnant Wistar rat was fed independently and gave birth naturally at 22 days of gestation. Newborn rats were randomly allocated to either the BPD model group $(n=80)$ or the control group $(n=80)$ within $12 \mathrm{~h}$ after birth. Newborn rats in the BPD model group were placed in a plexiglass oxygen tank and subjected to $95 \%$ oxygen inhalation for 1 to 21 days; an oxygen analyzer was used to continuously monitor the oxygen concentration. The tank was opened for $10 \mathrm{~min}$ and nursing rat dams were switched every $24 \mathrm{~h}$ between the hyperoxia and normoxia tanks to avoid oxygen toxicity. Newborn rats in the control group inhaled fresh air as opposed to hyperbaric oxygen; however, all other experimental conditions and control factors were the same as those for the BPD model group. Eight animals were euthanized and lung tissue was collected at each time-point (1, 3, 7, 14 and 21 days). The left lungs were fixed in $4 \%$ paraformaldehyde for hematoxylin and eosin $(\mathrm{H} \& \mathrm{E})$ staining and immunofluorescence assay. The right lungs were preserved in liquid nitrogen for mRNA detection and western blot analysis. All animal procedures were evaluated and approved by the Experimental Animal Ethics Committee of China Medical University, Shenyang, China.

AT2 cell isolation and purification. Another 8 animals were euthanized and AT2 cells were isolated at each time-point (1, $3,7,14$ and 21 days), respectively in each group. AT2 epithelial cells were isolated from the newborn rat lungs as previously described (6). The isolated AT2 cells were frozen at $-80^{\circ} \mathrm{C}$ for real-time PCR and western blot analysis.

RLE-6TN cultures and groups. RLE-6TN cells constitute a cell line derived from rat AT2 cells that was purchased from the American Type Culture Collection (ATCC; Manassas, VA, USA). The Runx3 expression plasmid and the double-stranded siRNAs against rat Runx3 were synthesized by Shanghai Genebank Co. Lipophilic transfection reagent (Lipofectamine 2000; Invitrogen Life Technologies, Carlsbad, CA, USA) was used. Human transforming growth factor- $\beta 1$ (TGF- $\beta 1$ )-mammalian was purchased from PeproTech, Inc. (Rocky Hill, NJ, USA).

The cells were grown on 6-well plates in Dulbecco's modified Eagle's medium (DMEM), nutrient mixture F-12 Ham supplemented with $10 \%$ fetal bovine serum (FBS), $40 \mathrm{mmol} / 1$ HEPES at $37^{\circ} \mathrm{C}$ in a humidified $5 \% \mathrm{CO}_{2}$ atmosphere (18). The cells were divided into 5 groups according to the different interventional methods as follows: the control group (untransfected RLE-6TN cell monolayer), the Runx3 group (transfected with Runx3 overexpression plasmid for $72 \mathrm{~h}$ ), the siRunx3 group (Runx3-deficient RLE-6TN cell monolayer transfected with siRNA of Runx3 for $72 \mathrm{~h})$, the TGF- $\beta 1$ group $(2.5 \mathrm{ng} / \mathrm{ml}$ TGF- $\beta 1$ was used to treat the RLE-6TN cell monolayer followed by culture for $48 \mathrm{~h}$ ), the Runx 3 + TGF- $\beta 1$ group (transfected with Runx 3 overexpression plasmid for $24 \mathrm{~h}$, and then $2.5 \mathrm{ng} / \mathrm{ml}$ TGF- $\beta 1$ was used followed by culture for the next $48 \mathrm{~h}$ ).

Generation of Runx3-overexpressing RLE-6TN cells. The pFlag-control and pFlag-Runx3 expression plasmids were both purchased from Genechem (Shanghai, China). Transfection with the pFlag-control and the pFlag-Runx3 plasmids into the RLE-6TN cells was carried out using Lipofectamine 2000 transfection reagent (Invitrogen Life Technologies) following the manufacturer's instructions. At $72 \mathrm{~h}$ after transfection, western blot analysis and real-time PCR were used, respectively for the analysis of protein and mRNA analysis. For immunofluorescence experiments, the cells were seeded on $22 \mathrm{~mm}$ round coverslips.

Silencing by small interfering RNA (siRNA). Logarithmically growing RLE-6TN cells were seeded at a density of $10^{5}$ cells and transfected with siRNA against Runx 3 using Lipofectamine (Invitrogen Life Technologies) following the manufacturer's instructions. At $72 \mathrm{~h}$ after transfection, lysates were prepared and analyzed by SDS-PAGE and immunoblotting, anhd realtime PCR was used for the analysis of mRNA expression. Immunofluorescence experiments were also carried out.

Stimulation of RLE-6TN cells with TGF- $\beta 1$. Confluent cultures $(70 \%)$ of RLE-6TN cells were maintained in serumfree medium for $24 \mathrm{~h}$. The cells were stimulated with $2.5 \mathrm{ng} /$ $\mathrm{ml}(100 \mathrm{pmol} / \mathrm{l})$ TGF- $\beta 1$ for the next $48 \mathrm{~h}$. The collected cells after stimulation were use for mRNA detection, immunofluorescence and western blot analysis.

Runx3-overexpressing RLE-6TN cells stimulated with $T G F-\beta 1$. Transfection of the pFlag-Runx3 plasmids into the RLE-6TN cells was carried out as mentioned above. Twentyfour hours later, the cells were stimulated with $2.5 \mathrm{ng} / \mathrm{ml}$ 
Table I. Primers design for real-time PCR.

\begin{tabular}{|c|c|c|c|c|c|}
\hline Names & Primer sequences & Distribution & $\operatorname{AT}\left({ }^{\circ} \mathrm{C}\right)$ & $\begin{array}{l}\text { Product } \\
\text { size (bp) }\end{array}$ & $\begin{array}{l}\text { Extension } \\
\text { time (sec) }\end{array}$ \\
\hline Runx3 & $\begin{array}{l}\text { F: 5'-GCAACGCTTCCGCTGTCA-3' } \\
\text { R: 5'-GGCTTTGGTCTGGTCCTCTATC-3' }\end{array}$ & $\begin{array}{l}\text { NM_130425 } \\
368-582\end{array}$ & 60 & 215 & 34 \\
\hline$S P C$ & $\begin{array}{l}\text { F: 5'-GCCAGTTTCGCATTCC-3' } \\
\text { R: 5'-GCTTATAGGCGGTCAGG-3' }\end{array}$ & $\begin{array}{l}\text { NM_017342 } \\
76-357\end{array}$ & 60 & 282 & 34 \\
\hline$\alpha-S M A$ & $\begin{array}{l}\text { F: 5'-CTTGCTAACGGAGGCG-3' } \\
\text { R: 5'-TCCAGAGTCCAGCACAATA-3' }\end{array}$ & $\begin{array}{l}\mathrm{BC} 158550 \\
366-525\end{array}$ & 60 & 160 & 34 \\
\hline$E-c a d$ & $\begin{array}{l}\text { F: 5'-ACAGTCAAACGGCATCTAA-3' } \\
\text { R: 5'-GGTGAAAGCTGGGAAAC-3' }\end{array}$ & $\begin{array}{l}\text { NM_031334 } \\
388-577\end{array}$ & 60 & 190 & 34 \\
\hline$N-c a d$ & $\begin{array}{l}\text { F: 5'-GACCCAGAAGATGATGTAAG-3' } \\
\text { R: 5'-CTCAGCGTGGATAGGC-3' }\end{array}$ & $\begin{array}{l}\text { NM_031333.1 } \\
2617-2787\end{array}$ & 60 & 171 & 34 \\
\hline$\beta$-actin & $\begin{array}{l}\text { R: 5'-CGTGCGTGACATTAAAGAG-3' } \\
\text { F: 5'-TTGCCGATAGTGATGACCT-3' }\end{array}$ & $\begin{array}{l}\text { NM_031144 } \\
702-833\end{array}$ & 60 & 132 & 34 \\
\hline
\end{tabular}

F, forward; R, reverse; SPC, surfactant protein C; $\alpha$-SMA, $\alpha$-smooth muscle actin; E-cad, E-cadherin; N-cad, N-cadherin.

TGF- $\beta 1$ for the next $48 \mathrm{~h}$. The collected cells were stored at $-80^{\circ} \mathrm{C}$ for mRNA detection and western blot analysis. For immunofluorescence experiments, the cells were seeded on $22 \mathrm{~mm}$ round coverslips. For ultrastructural analysis by transmission electron microscopy (TEM), the collected cells from the 5 different groups were fixed in $2.5 \%$ glutaraldehyde.

Validation of Runx3 plasmid transfection and siRNA interference effects. In order to validate the effects of Runx3 plasmid transfection and siRNA interference, we collected RLE-6TN cells at 48 and $72 \mathrm{~h}$ post-transfection and measured Runx 3 protein and mRNA expression using western blot analysis and real-time PCR.

Analysis of Runx3 in lung tissues and isolated AT2 cells. Runx 3 protein expression in lung tissues and AT2 cells was analyzed by western blot analysis. Total protein extracted from the right lung tissue or isolated AT2 cells was quantified using the BCA protein assay kit (Pierce Biotechnology. Rockford, IL, USA). Equivalent amounts of protein were separated using $10 \%$ SDS-PAGE gels and transferred onto polyvinylidene difluoride (PVDF) membranes (Millipore Billerica, MA, USA). The membranes were incubated for $1 \mathrm{~h}$ in $10 \%$ normal donkey serum to block non-specific binding. Next, the membranes were incubated, respectively with primary antibodies against Runx3 (1:1,000, ab49117) and $\beta$-actin (1:1,000, mouse monoclonal [ACTN05 (C4)] to actin; ab3280) (both from Abcam, Hong Kong, China) diluted in phosphate-buffered saline (PBS) incubated overnight at $4^{\circ} \mathrm{C}$. The following day, after being washed in Tris-buffered saline with $1 \%$ Tween-20 (TBST), the membranes were incubated for $2 \mathrm{~h}$ in horseradish peroxidaseconjugated secondary antibodies (cat. nos. 31466 and 31430; Thermo Fisher Scientific, Waltham, MA, USA), then imaged by enhanced chemiluminescence reagents. ImageJ software was used to analyze the optical density of protein bands and then normalized to that of $\beta$-actin.
Real-time PCR was used to examine Runx3 mRNA expression. Total RNA was extracted from right lung lobes or isolated AT2 cells using TRIzol reagent and frozen at $-80^{\circ} \mathrm{C}$ (Invitrogen Life Technologies, Camarillo, CA, USA) according to the manufacturer's instructions. A total of $1 \mu \mathrm{g}$ RNA from each sample was reverse-transcribed into cDNA using SuperScript III according the manufacturer's instructions (SuperScript III; Invitrogen Life Technologies). Real-time PCR was performed on a LightCycler (7500 Fast Real-Time PCR system; Applied Biosystems, Foster City, CA, USA) using appropriate primers designed by Primer Premier 5.0 software (Premier Biosoft International, Palo Alto, CA, USA; Table I). The amplification reaction was carried as follows: $95^{\circ} \mathrm{C}$ for $30 \mathrm{sec}\left(95^{\circ} \mathrm{C}\right.$ for $5 \mathrm{sec}$, $60^{\circ} \mathrm{C}$ for $\left.34 \mathrm{sec}\right) 40$ cycles. The relative level of mRNA expression was calculated following normalization to $\beta$-actin.

Analysis of surfactant protein C (SPC), $\alpha$-smooth muscle actin ( $\alpha$-SMA), E-cadherin (E-cad) and N-cadherin ( $N$-cad) levels in RLE-6TN cells. The expression levels of proteins involved in EMT (SPC, SMA, E-cad and N-cad) in RLE-6TN cells were analyzed by western blot analysis as mentioned above. The antibody concentrations were as follows: SPC (1:100, goat polyclonal antibody; sc-7706; Santa Cruz Biotechnology, Inc., Santa Cruz, CA, USA), $\alpha$-SMA (1:500, mouse monoclonal to $\alpha$-SMA; ab7817; Abcam), E-cad (1:1,000, rabbit polyclonal to E-cad; GTX100443, GeneTex, Irvine, CA, USA), N-cad (1:1,000, mouse monoclonal to N-cad; ab98952; Abcam) or $\beta$-actin $(1: 1,000$, mouse monoclonal [ACTN05 (C4)] to actin; ab3280; Abcam). ImageJ software was used to analyze the optical density of the protein bands and then normalized to that of $\beta$-actin.

The mRNA expression of SPC, $\alpha$-SMA, E-cad, N-cad in the RLE-6TN cells was analyzed by real-time PCR as mentioned above. The primers and amplification conditions are shown in Table I. The relative level of mRNA expression was calculated following normalization to $\beta$-actin. 
Double-label immunofluorescence assay for RLE-6TN cells. The RLE-6TN cells were cultured, respectively on glass slides in the 5 groups, fixed with $4 \%$ paraformaldehyde and permeabilized with $0.5 \%$ Triton X-100, then washed 3 times with PBS. The sections were subsequently incubated in 5\% FBS for $30 \mathrm{~min}$ for antigen blocking. The slides were then incubated with a mixture of two primary antibodies [anti-SPC (1:100 diluted, goat polyclonal antibody; sc-7706; Santa Cruz Biotechnology, Inc.) and $\alpha$-SMA (1:100 diluted, mouse monoclonal to $\alpha$-SMA; ab7817; Abcam) at $-4^{\circ} \mathrm{C}$ overnight. Normal goat IgG (sc-2028) or normal mouse IgG (sc-2025) (both from Santa Cruz Biotechnology, Inc.) was used respectively in place of the primary antibodies in the negative control samples. The slides were then washed 3 times with PBS and then incubated with a mixture of two secondary antibodies [anti-mouse antibody (Alexa Fluor-488, green fluorescence) and anti-goat antibody (Alexa Fluor-594, red fluorescence)] at $37^{\circ} \mathrm{C}$ for $60 \mathrm{~min}$. Subsequently, the sections were further washed with PBS 3 times and then subjected to DAPI (1:2,000; Sigma-Aldrich, St. Louis, MO, USA) nuclear staining for $5 \mathrm{~min}$. After washing thoroughly with PBS, images of the sections were acquired using a fluorescence microscope at x400 magnification.

TEM. The RLE-6TN cells collected, respectively from the 5 different groups were fixed in PBS solution ( $\mathrm{pH} 7.4)$ containing $2.5 \%$ glutaraldehyde for $2 \mathrm{~h}$, washed with PBS 3 times, post-fixed in $1 \%$ osmium tetroxide for $2 \mathrm{~h}$, washed with distilled water 3 times, dehydrated with gradient ethanol and acetone, and immersed in Epon 812 overnight; the lung tissue blocks were then embedded in Epon 812 and cut into ultrathin sections $(60 \mathrm{~nm})$. The ultrathin sections were doublestained with uranyl acetate and aluminum citrate and cellular morphology was observed under a transmission electron microscope (Hitachi H-7650; Hitachi Co., Tokyo, Japan).

Pathology and morphometry. The left lung tissues were fixed in $4 \%$ paraformaldehyde for $24 \mathrm{~h}$, dehydrated with gradient ethanol, vitrified with xylene, embedded in paraffin, cut into sections $(5 \mu \mathrm{m})$ and stained with H\&E (G1120; Solarbio Life Sciences, Beijing, China). Morphological changes were assessed using an optical microscope (x40 magnification). Ten fields were randomly selected for analysis from each section to evaluate the development of pulmonary alveoli. The radial alveolar count (RAC) developed by Emery and Mithal (19) was determined. Scion Image software (Scion Corp., Frederick, MD, USA) was used to measure alveolar wall thickness (20). Immunofluorescence assay for $\alpha$-SMA in lung tissues was carried out according to our previously described methods (6). The number of branch points per millimeter squared and surface density of secondary septa were calculated by computer-assisted image analysis as previously described (21), and the percentage of SMA-positive secondary septa was calculated. Each section was evaluated by two independent pathologists who were blinded to the experimental design.

Statistical analysis. We used SPSS 11.5 software (SPSS, Inc., Chicago, IL, USA) for statistical analysis. Values are presented as the means \pm standard deviation (SD); an independent-sample t-test was used to compare differences between 2 groups.
One-way analysis of variance (ANOVA) was used to determine the significant difference among multiple groups. Pearson's test was applied for correlation analyses. Statistical significance was assessed at $\mathrm{P}<0.05$. A $\mathrm{P}$-value $<0.05$ was considered to indicate a statistically significant difference.

\section{Results}

Protein and mRNA expression of Runx 3 in lung tissues and isolated AT 2 cells. On days 1 and 3, the protein expression level of Runx3 in lung tissue did not differ significantly between the 2 groups. On day 7, Runx3 protein expression in the control group remained high, while Runx3 protein expression progressively decreased in the BPD group. On days 7, 14 and 21, the protein expression level of Runx3 in the control group was significantly higher than that in the BPD group $(\mathrm{P}<0.01)$ (Fig. 1A and $\mathrm{C}$ ). Similarly, no significant difference in Runx3 mRNA expression was observed between the 2 groups on days 1 or 3 , while the Runx3 mRNA expression level was significantly higher in the control group than in the BPD group on days 7, 14 and 21 $(\mathrm{P}<0.01)$ (Fig. 1D).

In the AT2 cells isolated from primary rats at different time points, no significant differences in both Runx 3 protein and mRNA expression were observed between the 2 groups on days 1 and 3. On day 7 and at later time points, the Runx3 protein expression level in the control group was markedly higher than that in the BPD group $(\mathrm{P}<0.01)$ (Fig. $1 \mathrm{~B}$ and $\mathrm{E})$. On days 7, 14 and 21, the Runx3 mRNA expression level in the control group was significantly greater than that in the BPD group $(\mathrm{P}<0.01)$ (Fig. 1F).

Effects of ectopic Runx3 expression and siRNA interference. At $48 \mathrm{~h}$ following transfection with the Runx3 plasmid, the increased mRNA expression of Runx3 was observed; Runx3 mRNA expression was higher at both 48 and $72 \mathrm{~h}$ posttransfection as compared to time $0(\mathrm{P}<0.01)$ (Fig. 2B). Similarly, the Runx3 protein expression level increased beginning at $48 \mathrm{~h}$ post-transfection and it was also significantly higher at 48 and $72 \mathrm{~h}$ post-transfection as compared to time $0(\mathrm{P}<0.01)$ (Fig. 2A and $\mathrm{C})$. At $48 \mathrm{~h}$ following transfection of the cells with siRNA, Runx3 mRNA expression was decreased; Runx3 mRNA expression 24, 48 and $72 \mathrm{~h}$ post-siRNA transfection was lower than that at time $0(\mathrm{P}<0.01)$ (Fig. 2B). Similarly, the Runx3 protein expression level began to decrease beginning at $48 \mathrm{~h}$ post-siRNA transfection and it remained lower at 48 and $72 \mathrm{~h}$ post-transfection than at time $0(\mathrm{P}<0.01)$ (Fig. 2A and $\mathrm{C})$.

Expression of SPC, SMA, E-cad, N-cad in RLE-6TN cells. The protein expression of SPC, $\alpha$-SMA, E-cad and N-cad in the 5 RLE-6TN cell groups was measured. The protein expression levels of the mesenchymal cell markers, $\alpha$-SMA and N-cad, in the TGF- $\beta 1$ and siRunx3 groups were significantly higher than those in the control group $(\mathrm{P}<0.01$; Fig. $3 \mathrm{~A}$ and $\mathrm{B})$, while the protein expression levels of the epithelial cell markers, SPC and E-cad, were significantly lower than those in the control group $(\mathrm{P}<0.01$; Fig. 3A and $\mathrm{B})$. No significant differences in either the epithelial or the mesenchymal cell markers were found between the Runx3 overexpression group or the Runx3 + TGF- $\beta 1$ group and the control group (Fig. 3A and B). 
$\mathbf{A}$

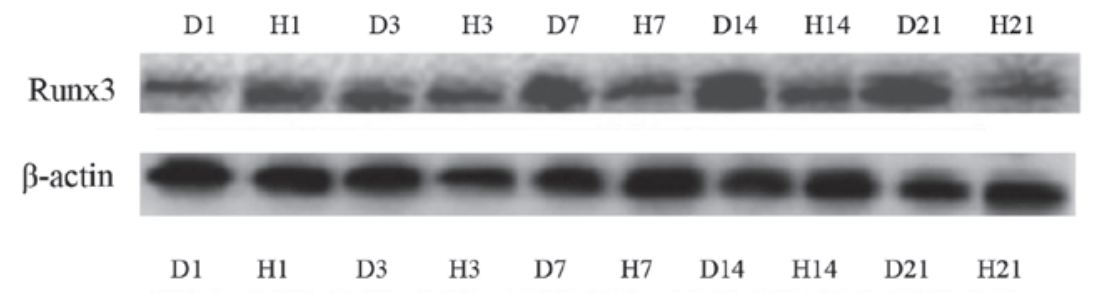

B

Runx3

$\beta$-actin

C

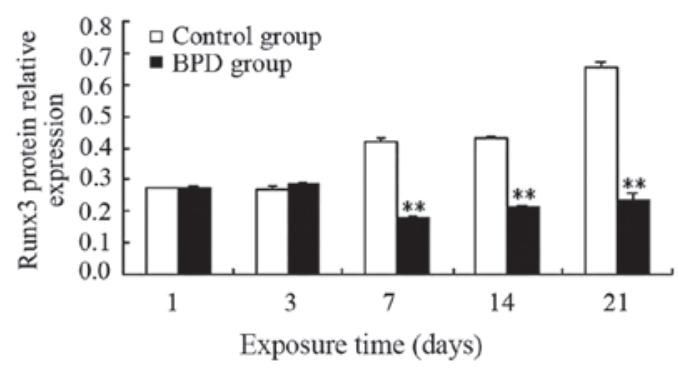

E

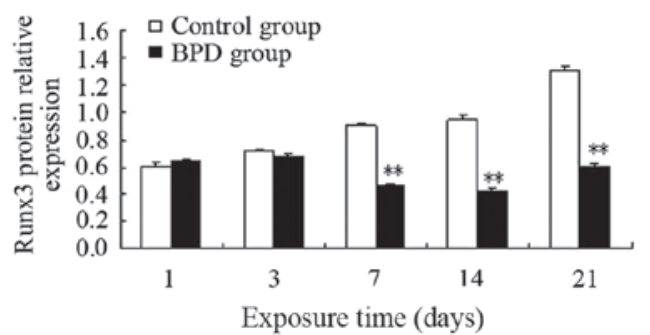

D

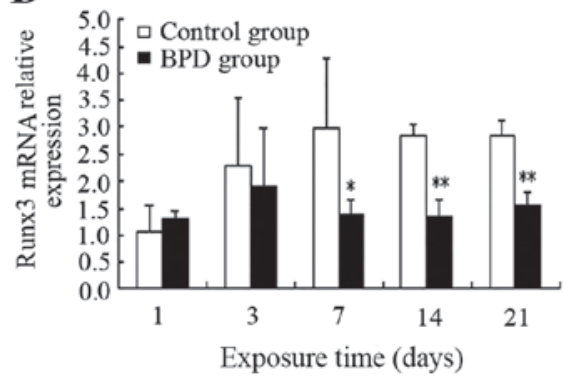

F

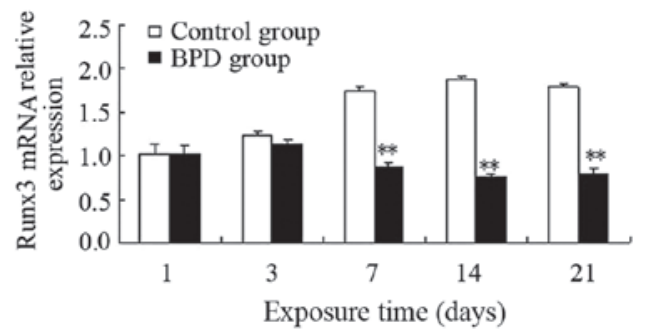

Figure 1. Runx3 expression in lung tissues and isolated AT2 cells. (A and C) The protein expression and (D) mRNA level of Runx3 from lung tissues in the control group was significantly higher than that in THE bronchopulmonary dysplasia (BPD) group ON days 7, 14 and 21. (B and E) The protein expression and (F) mRNA level of Runx 3 from isolated AT2 cells in the control group was also significantly higher than that in THE BPD group ON days 7, 14 and 21 . Values are presented as THE means $\pm \mathrm{SD} ;{ }^{*} \mathrm{P}<0.05,{ }^{* *} \mathrm{P}<0.01$ vs. control group. $\mathrm{D}$, refers to the control group; $\mathrm{H}$, to the $\mathrm{BPD}$ group, and the digit for the number of days after birth.

A

siRunx3
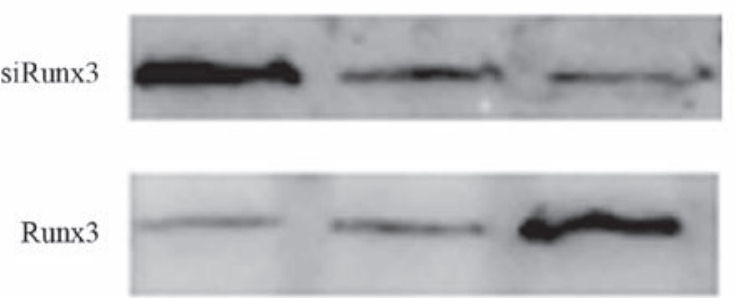

$\beta$-actin

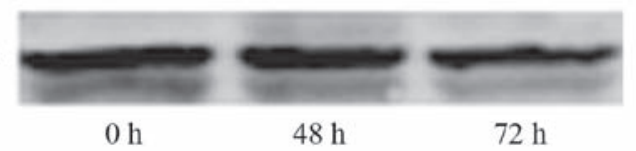

B

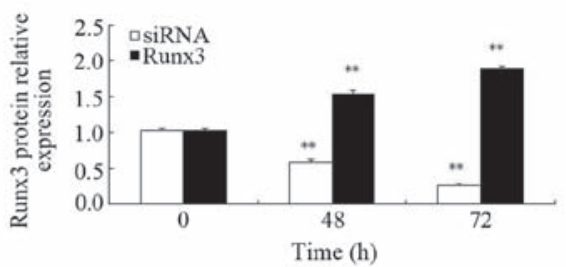

C

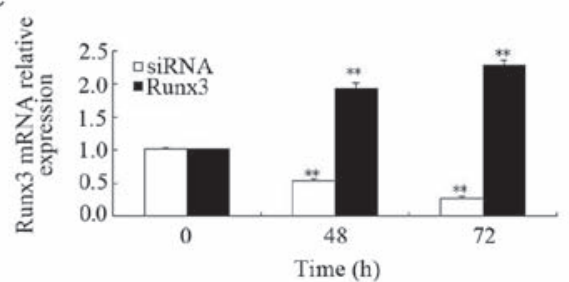

Figure 2. Effects of ectopic Runx3 expression and siRNA interference. (A-C) Protein and mRNA expression of Runx 3 were increased at both 48 and $72 \mathrm{~h}$ post-transfection as compared to time 0 . Runx $3 \mathrm{mRNA}$ and protein expression 24,48 and $72 \mathrm{~h}$ post-siRNA transfection were lower than that at time 0 . Values are presented as the means $\pm \mathrm{SD} ;{ }^{* *} \mathrm{P}<0.01$ vs. time 0 .

Similarly, the mRNA expression levels of $\alpha$-SMA and N-cad in the TGF- $\beta 1$ group and siRunx3 group were significantly higher than those in the control group $(\mathrm{P}<0.01$; Fig. $3 \mathrm{C})$, while the mRNA expression levels of SPC and E-cad were signifi- 
A
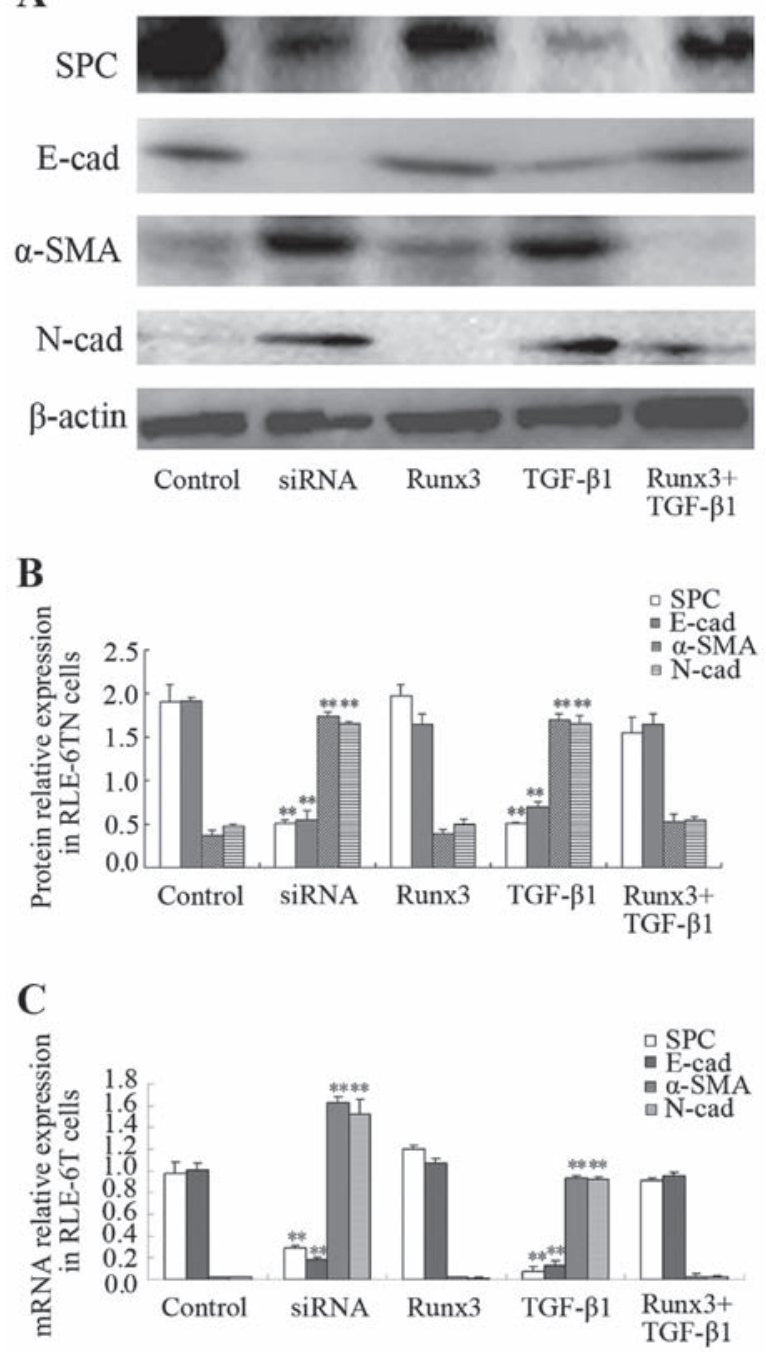

Figure 3. (A-C) Expression of surfactant protein C (SPC), $\alpha$-smooth muscle actin ( $\alpha$-SMA), E-cadherin (E-cad) and N-cadherin (N-cad) in RLE-6TN cells . The control group (untransfected RLE-6TN cell monolayer), Runx3 group (transfected with Runx3 overexpression plasmid for $72 \mathrm{~h}$ ), siRunx 3 group (Runx3 deficient RLE-6TN cell monolayer transfected with siRNA of Runx3 for $72 \mathrm{~h}$ ), transforming growth factor- $\beta 1$ (TGF- $\beta 1)$ group $(2.5 \mathrm{ng} / \mathrm{ml}$ TGF- $\beta 1$ was used to treat the RLE-6TN cell monolayer followed by culture for $48 \mathrm{~h}$ ), Runx 3 + TGF- $\beta 1$ group (transfected by Runx 3 overexpression plasmid for $24 \mathrm{~h}$, then $2.5 \mathrm{ng} / \mathrm{ml}$ TGF- $\beta 1$ was used and cultured for the next $48 \mathrm{~h}$ ). Values are presented as the means $\pm \mathrm{SD} ;{ }^{* *} \mathrm{P}<0.01$ vs. control group.

cantly lower than those in control group $(\mathrm{P}<0.01$; Fig. $3 \mathrm{C})$. No significant differences in either the epithelial cell markers or the mesenchymal cell markers were found between the Runx3 overexpression group or the Runx $3+$ TGF- $\beta 1$ group and the control group (Fig. 3C).

Double-label immunofluorescence assay. SPC is a specific marker of AT2 cells, while $\alpha$-SMA is a marker of mesenchymal cells; their co-expression suggests EMT occurrence in RLE-6TN cells. Using two-color immunofluorescence staining we found that in both the control group and the Runx3 group, SPC was expressed in the cytoplasm (red fluorescence), while the expression of $\alpha$-SMA was not detectable (green fluorescence). In the TGF- $\beta 1$ group and the siRunx 3 group, SPC expression was not observed, yet $\alpha$-SMA expression was detectable in the cytoplasm. However, in the Runx3 + TGF- $\beta 1$ group, a large amount of SPC expression and a trace amount of $\alpha$-SMA expression were found (Fig. 4).

Ultrastructural evidence of EMT in RLE-6TN cells. We observed the ultrastructure changes of the 5 RLE-6TN groups by TEM. The normal ultrastructure of RLE-6TN cells (microvilli on cell surface and lamellar bodies in the cells) was observed in the control group, the Runx3 group and the Runx3 + TGF- $\beta 1$ group (Fig. 5A). However, in the TGF- $\beta 1$ group and the siRunx3 group, there were a large number of sparse actin microfilaments and some fasciculated actin microfilaments in the cytoplasm of the RLE-6TN cells (Fig. 5B and C).

Comparisonofpulmonarydevelopment indicators. The sections were stained with $\mathrm{H} \& \mathrm{E}$. Morphological changes were assessed using an optical microscope (x40 magnification; Fig. 6). On days 1 and 3, there was no significant difference in the RAC between the 2 groups; however, on days 7, 14 and 21, the RAC of the control group was significantly greater than that of the BPD group ( $\mathrm{P}<0.01$; Fig. 7A). On days 7, 14 and 21, the alveolar wall thickness in the BPD group was significantly greater than that in control group $(\mathrm{P}<0.01$; Fig. $7 \mathrm{~B})$. On days 1 and 3 , $\alpha$-SMA expression in the lung tissues did not differ significantly between the 2 groups; $\alpha$-SMA was primarily expressed at the top of secondary septa in the control group samples, but was expressed in the pulmonary mesenchyma in the BPD samples beginning on day 7. On days 7, 14 and 21 the percentage of $\alpha$-SMA-positive secondary septa in the control group was markedly higher than that in the BPD group (Figs. 7C and 8).

Analysis of the correlation between Runx3 protein expression in lung tissue and pulmonary development indicators. In the control group, the RAC gradually increased in direct correlation with the increase in Runx3 protein expression; Spearman correlation analysis revealed that Runx 3 protein expression positively correlated with RAC ( $\mathrm{r}=0.925, \mathrm{P}<0.01$; Fig. 9A). In the BPD group, Runx3 protein expression and RAC both decreased gradually over time; Runx 3 protein expression positively correlated with $\mathrm{RAC}(\mathrm{r}=0.427, \mathrm{P}<0.01$; Fig. 9B). In the control group, the alveolar wall became thinner with time and Spearman correlation analysis indicated that Runx3 protein expression negatively correlated with alveolar wall thickness ( $\mathrm{r}=-0.95, \mathrm{P}<0.01$; Fig. $9 \mathrm{C}$ ); by contrast, in the BPD group, the alveolar wall became thicker over time although Runx3 protein expression remained negatively correlated with alveolar wall thickness ( $\mathrm{r}=-0.96, \mathrm{P}<0.01$; Fig. 9D). In the control group, Runx3 protein expression positively correlated with the percentage of $\alpha$-SMA-positive secondary septa $(\mathrm{r}=-0.832, \mathrm{P}<0.01$; Fig. 9E), while in the BPD group, both Runx3 protein expression and the percentage of $\alpha$-SMA-positive secondary septa in lung tissue gradually decreased over time. Spearman correlation analysis indicated that Runx3 protein expression positively correlated with the percentage of $\alpha$-SMA-positive secondary septa within the BPD group ( $\mathrm{r}=-0.914, \mathrm{P}<0.01$; Fig. $9 \mathrm{~F})$.

\section{Discussion}

In mammals, the Runx family of transcription factors includes three genes: Runx1, 2 and 3. Each member contains a highly conserved runt domain and their gene products are similar in 


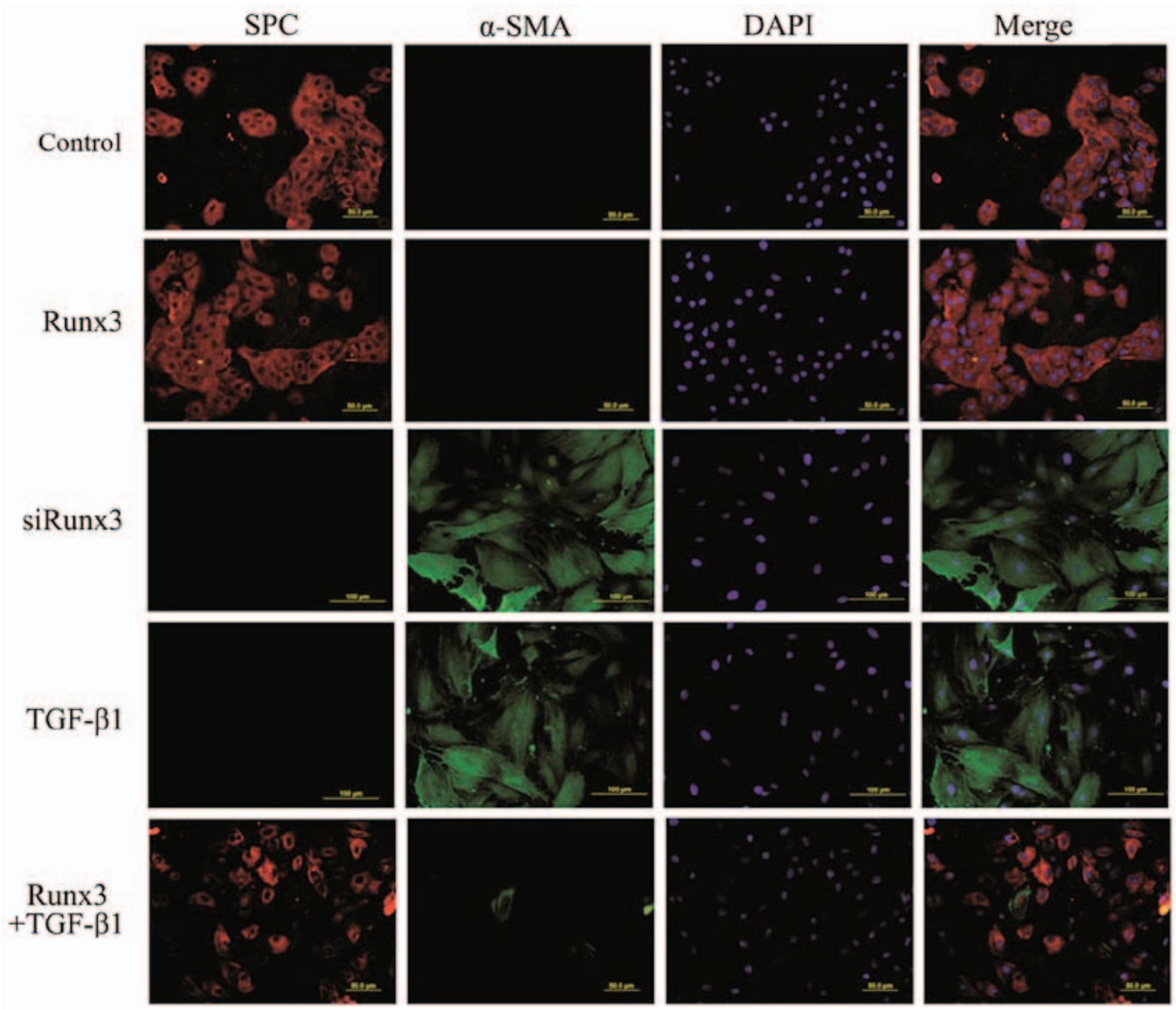

Figure 4. Double-label immunofluorescence assay in RLE-6TN cells. Surfactant protein C (SPC), red fluorescence; $\alpha$-smooth muscle actin ( $\alpha$-SMA), green fluorescence; nucleus, blue fluorescence. In both the control and the Runx3 groups, SPC was expressed in the cytoplasm. In the transforming growth factor- $\beta 1$ (TGF- $\beta 1$ ) group and the siRunx3 group, $\alpha$-SMA expression was detectable in the cytoplasm. In the Runx $3+$ TGF- $\beta 1$ group, a large amount of SPC expression and a trace amount of $\alpha$-SMA expression were found.
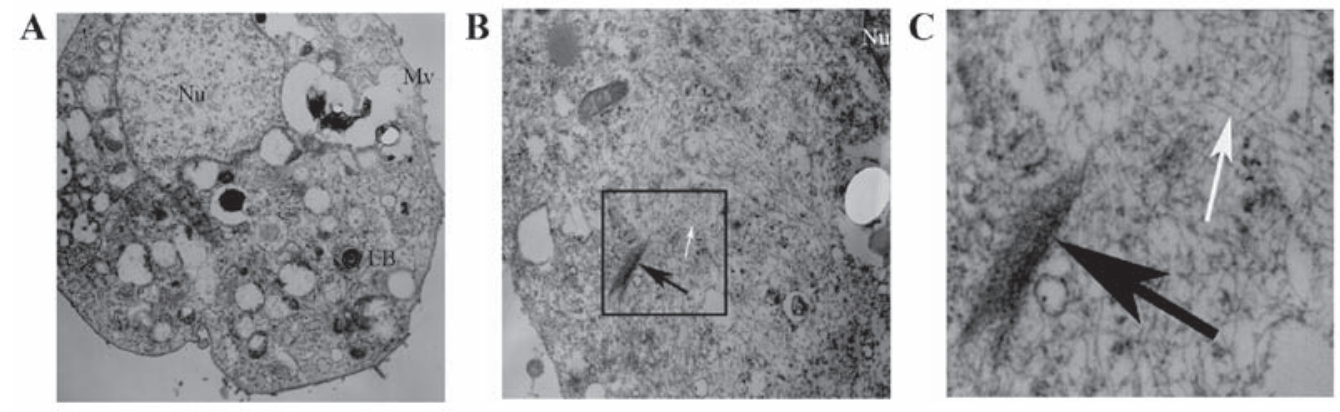

Figure 5. Ultrastructure in RLE-6TN cells. (A) Normal ultrastructure of RLE-6TN cells, microvilli (Mv) on cell surface and lamellar bodies (LB) in the cells can be seen in the control group, the Runx3 group and the Runx3 + TGF- $\beta 1$ group. All 3 groups are shown here in one image, as they all showed a normal ultrastructure of alveolar type 2 epithelial cells. (B and C) A large number of sparse actin microfilaments (white arrows) and some fasciculated actin microfilaments (black arrows) in the cytoplasm in the TGF- $\beta 1$ group and the siRunx3 group.

structure; however,each memberhas different biological functions and demonstrates tissue-specific expression. All Runx family members play an important role in the normal development of the body, as well as the tumor formation (22). Runx1 participates in hematopoiesis; for example, the development of leukemia is often associated with a change in the expression of Runx1 (23). Runx 2 is associated with osteoporosis; changes in Runx2 expression are associated with cleidocranial dysplasia (24) and osteosarcoma (25). Runx3 is the smallest member of the Runx family and acts to inhibit tumor formation (26). Human Runx3 is located at chromosome 1p36.1 (27). Human Runx3 is $67 \mathrm{~kb}$ long and contains two promoters (P1 and P2) and 6 exons. Runx3 gene transcription is mainly controlled by $\mathrm{P} 2$ which is located at the front of exon 2 and surrounded by an obvious $\mathrm{CpG}$ island with a GC content of $\sim 64 \%$ (28).

The Runx 3 gene plays a regulatory role in pulmonary development (16), but also affects the occurrence of EMT (29). At E15.5d, the protein expression of Runx 3 has been shown to be low 


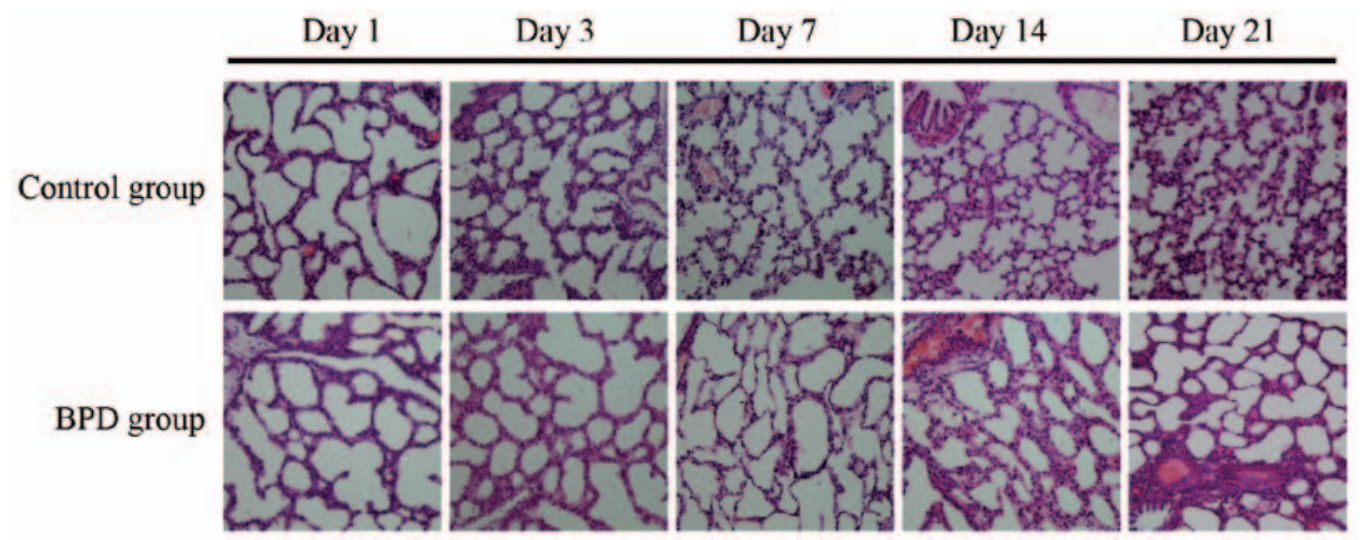

Figure 6. Pathology of bronchopulmonary dysplasia (BPD). From day 7, the number of alveoli and alveolar septa was significantly increased, the alveolar septa continued thinning and the number of alveoli increased in control group, while there was a decreased number of alveoli and increased alveolar wall thickness in tissues from the BPD model group.

A

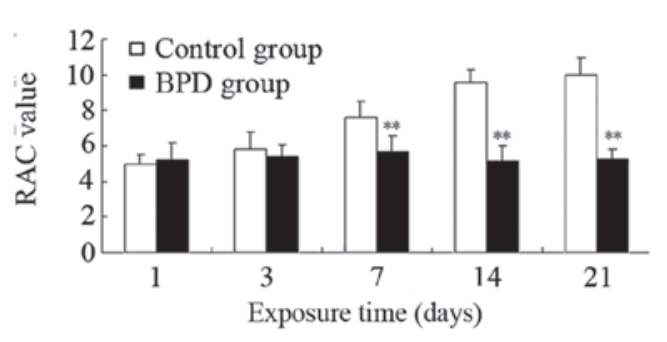

B

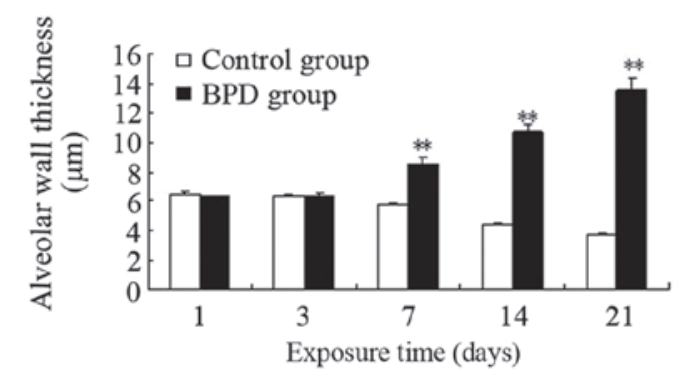

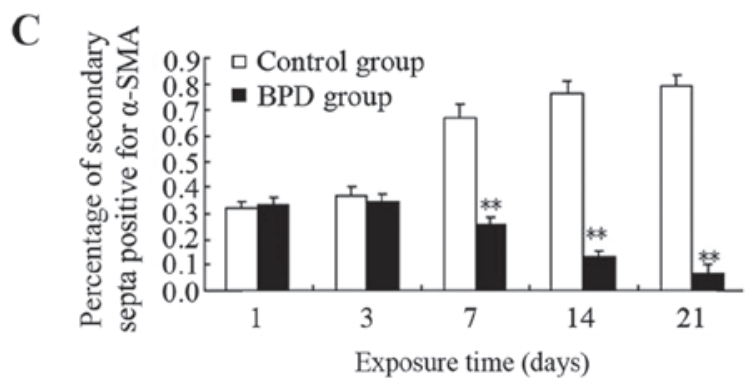

Figure 7. Comparison of radial alveolar count (RAC), alveolar wall thickness, the percentage of $\alpha$-smooth muscle actin-positive ( $\alpha$-SMA ${ }^{+}$) secondary septa between the two groups. (A) The RAC of the control group was significantly greater than that of the bronchopulmonary dysplasia (BPD) on days 7, 14 and 21. (B) The alveolar wall thickness in the BPD group was significantly greater than that in control group on days 7, 14 and 21 . (C) The percentage of $\alpha-S M A^{+}$secondary septa in the control group was markedly higher than that in the BPD group on days 7,14 and 21 . ${ }^{* *} \mathrm{P}<0.01$ vs. control group.

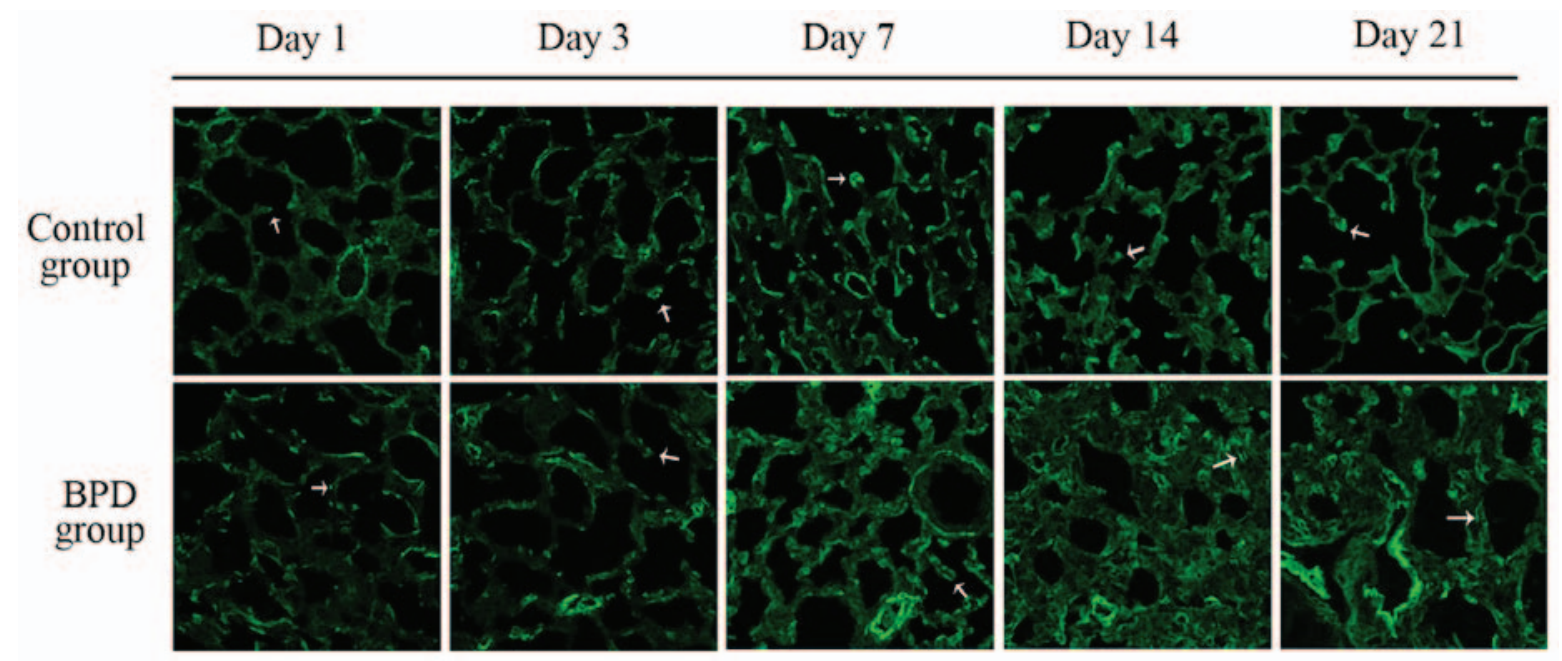

Figure 8. Immunofluorescence staining of $\alpha$-smooth muscle actin ( $\alpha$-SMA). $\alpha$-SMA (white arrows) was primarily expressed at the top of secondary septa in control group samples yet expressed in the pulmonary mesenchyma in bronchopulmonary dysplasia (BPD) samples beginning on day 7. 
A

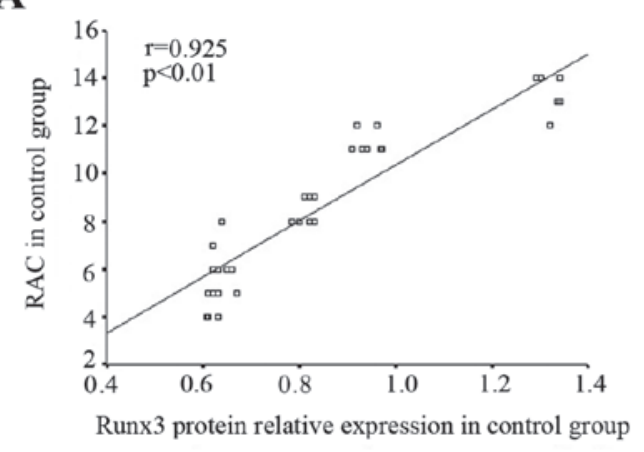

C

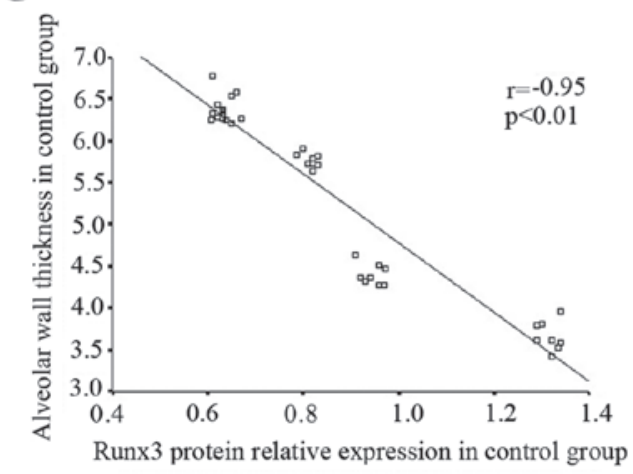

$\mathbf{E}$

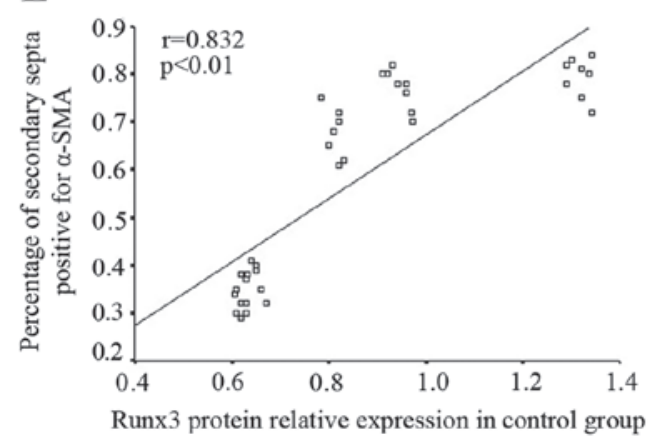

B

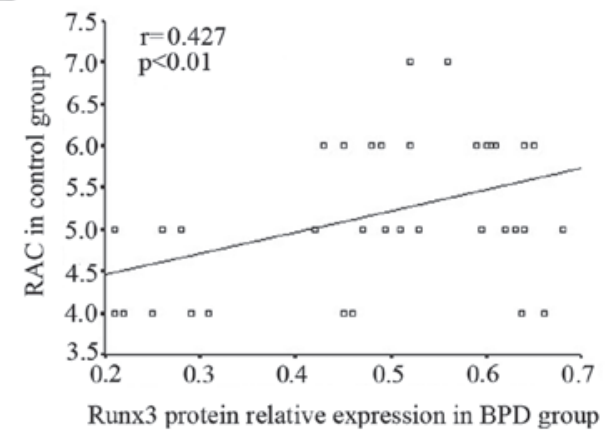

D

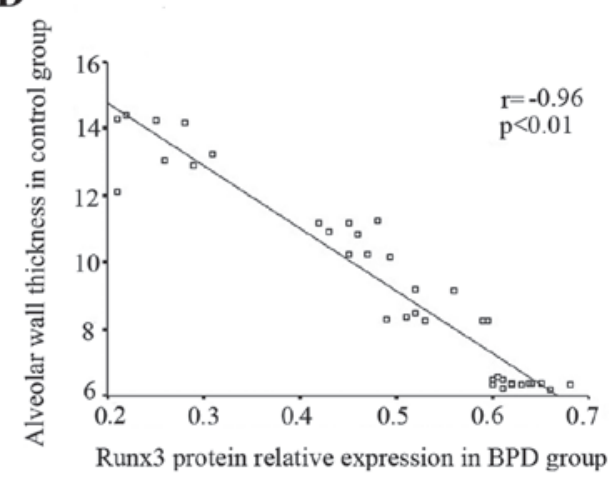

F

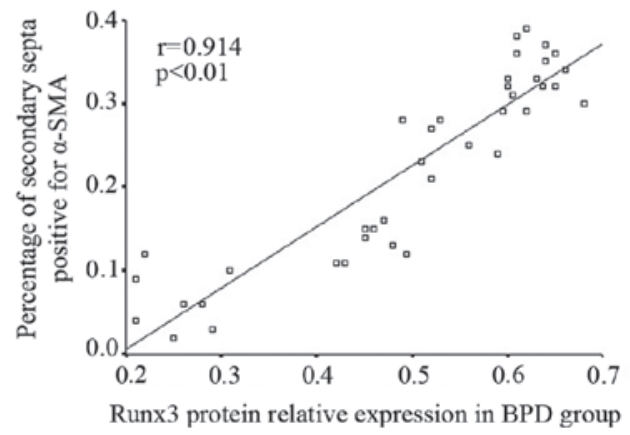

Figure 9. Correlation between Runx3 protein and pulmonary development indicators. (A and B) Runx3 protein expression positively correlated with the radial alveolar count (RAC). (C and D) Runx3 protein expression negatively correlated with alveolar wall thickness. (E and F) Runx3 protein expression positively correlated with the percentage of $\alpha$-smooth muscle actin-positive $\left(\alpha-\mathrm{SMA}^{+}\right)$secondary septa.

in wild-type fetal rats, while at E17.5d, Runx3 protein expression in bronchioles and alveoli increases gradually until the maturation phase (15). In this study, we demonstrated that Runx3 expression in control newborn rat lung tissue was significantly increased between 7 and 21 days after birth; by contrast, Runx 3 expression in newborn rat tissue from the BPD group was significantly lower than that in the control group. These data indicate that Runx3 expression in lung tissues was downregulated in the BPD group, perhaps due the abnormal pulmonary development present in this group.The suppressed Runx3 expression may also hinder normal pulmonary development of newborn rats with BPD. In order to further study Runx3 expression in AT2 cells, we isolated AT2 cells from lung tissue in two rat groups with different day ages and then measured the mRNA and protein expression of Runx3 in AT2 cells. We found that the protein and mRNA expression levels of Runx3 in BPD group were markedly lower than those in the control group on days 7, 14 and 21. Previously, we confirmed that EMT occurred in AT2 cells within the BPD group beginning at day 7 (6). Consistent with the above timeline, a decrease in Runx3 expression in AT2 cells within the BPD group also appeared beginning at day 7. Taking these data together with the finding in our previous study that Runx3 can inhibit the EMT process, we hypothesized that a low level of Runx3 in AT2 cells of BPD lung tissues may be associated with the occurrence of EMT.

EMT is a common biological phenomenon defined as the differentiation of epithelial cells into mesenchymal cells (30). During the development of EMT, the levels of epithelial cell markers (e.g., E-cadherin and occludin) gradually decrease (31), while those of mesenchymal cell markers (e.g., N-cadherin and $\alpha$-SMA) $(32,33)$ progressively increase. In order to verify the regulatory effect of Runx 3 on EMT in AT2 cells, we purchased a rat alveolar type II epithelial cell line (RLE-6TN) (ATCC) for Runx3 plasmid transfection and siRNA interference to 
observe the effects of changes in Runx3 expression on EMT. In addition, we stimulated the RLE-6TN cell line with TGF- $\beta 1$ to induce EMT and overexpressed Runx3 in RLE-6TN cells in combination with TGF- $\beta 1$ to observe the effects of Runx3 on TGF- $\beta 1$-induced EMT. TGF- $\beta 1$ is a common stimulator used to induce EMT in epithelial cells (34). We also used it to induce EMT in RLE-6TN cells, which was characterized by a decrease in the expression of epithelial cell markers (SPC and E-cad) and an increase in the expression of mesenchymal cell markers (N-cad and $\alpha$-SMA). In the present study, we found the decreased expression of SPC (an AT2 marker) and E-cad (an epithelial cell marker) and the increased expression of $\mathrm{N}$-cad and $\alpha$-SMA (mesenchymal cell markers) in Runx3-silent RLE-6TN cells, indicating the development of EMT. Thus, we can conclude that a decrease in Runx3 expression can directly promote the occurrence of EMT. It has been shown that a high level of TGF- $\beta 1$ is present in BPD lung tissue (35). The pathological changes present in the lungs of transgenic mice overexpressing TGF- $\beta 1$ are similar to those observed in BPD, which suggests that high levels of TGF- $\beta 1$ can contribute to the occurrence of BPD (36). We hypothesize that high levels of TGF- $\beta 1$ may be related to EMT occurrence in AT2 cells from BPD-affected lung tissue. EMT was directly induced using TGF- $\beta 1$ in RLE-6TN cells cultured under normal conditions, while it was not induced by stimulating Runx3-overexpressing RLE-6TN cells with TGF- $\beta 1$; specifically, epithelial cell markers were still highly expressed in the Runx $3+$ TGF- $\beta 1$ group. This indicates that a high level of Runx3 can suppress TGF- $\beta 1$-induced EMT.

Epithelial cells and mesenchymal cells have different morphologies and subcellular structures. Specific changes in subcellular structure are found during EMT in renal tubular epithelial cells $(37,38)$; based on these findings, we hypothesized that there may also be a similar change in AT2 cells experiencing EMT. Using TEM, we observed normal ultrastructure of AT2 cells within the control group, the Runx3 overexpression group, and the Runx $3+$ TGF- $\beta 1$ group (microvilli on cell surface and characteristic lamellar bodies in the cytoplasm). By contrast, we observed a larger number of sparse, fasciculated actin microfilaments, but no characteristic lamellar bodies in AT2 cells within the Runx3 gene knockdown group and TGF- $\beta 1$ stimulation group; these data indicate that AT2 cells completely transform into mesenchymal cells via EMT. The above-mentioned findings were confirmed at the ultrastructure level as well. Therefore, we conclude that a low level of Runx3 can directly promote the occurrence of EMT, while a high level of Runx3 has an inhibitory effect on EMT.

Runx3 can directly regulate the EMT process in AT2 cells; furthermore, EMT in AT2 cells of lung tissues may influence the normal development of alveoli. In order to evaluate the association between Runx3 and alveolar development, we performed a correlation analysis of Runx 3 protein expression and pulmonary development indicators at the level of lung tissue. RAC, alveolar wall thickness (39), and the percentage of $\alpha$-SMA-positive secondary septa (20) are the most important indicators of alveolar development. Correlation analysis revealed that Runx3 expression positively correlated with RAC and the percentage of $\alpha$-SMA-positive secondary septa, but negatively correlated with alveolar wall thickness. This study also demonstrated that in the lung tissues of the normal control group, $\alpha$-SMA was mainly expressed at the top of secondary septa and the percentage of
$\alpha$-SMA-positive secondary septa was increased significantly from day 7 to 21 after birth. In our previous study, we found that $\alpha$-SMA protein expression was sharply increased in the BPD group beginning at day 7 after birth, which was significantly greater than that in the control group (6). In this study, using immunofluorescence staining, we found that $\alpha$-SMA was distributed mainly in pulmonary mesenchyma and rarely in the top of secondary septa in BPD tissues, which is similar to the $\alpha$-SMA expression results obtained in a premature baboon model of BPD (40). These findings suggest that the correct localization of myofibroblasts is essential for normal pulmonary development and that increased myofibroblasts in the mesenchyma may promote the remodeling of lung tissues in BPD models.

Our study confirmed that Runx3 expression was decreased in the lung tissues of rats with BPD in vivo, that Runx3 expression closely correlated with pulmonary development indicators in vivo, and that Runx3 can promote EMT in AT2 cells in vitro. Therefore, we infer that a low level of Runx 3 in lung tissues may contribute to EMT occurrence in AT2 cells and thus influence the normal pulmonary development and promote the occurrence of BPD. The following factors are considered to be associated with the decreased expression of Runx3: methylation of its promoter region (41), histone modification (42), micro-RNA regulation (43), cytoplasmic allotopic expression $(44,45)$ and hemizygote absence (46). Further investigation into the mechanisms by which Runx 3 deficiency promtes BPD is necessary and may suggest therapeutic options for the treatment of neonatal BPD.

In conclusion, this study demonstrated that Runx 3 expression was decreased in BPD-affected lung tissue, and the lower Runx3, at least in part, impaired normal lung development and contributed to BPD by inducing EMT in AT2 cells. However, the mechanisms underlying the decreased expression of Runx 3 in BPD warrant further investigation.

\section{Acknowledgements}

We would like to thank Mr. Fugui Zhang (Central Laboratory of China Medical University) for providing instructions for the transmission electron microscope and Mr. Zhihong Zong (Central Laboratory of China Medical University) for providing technical support for real-time PCR. This study was funded by the Natural Science Foundation of China (nos. 81471489 and 81571479).

\section{References}

1. Fanaroff AA, Stoll BJ, Wright LL, Carlo WA, Ehrenkranz RA, Stark AR, Bauer CR, Donovan EF, Korones SB, Laptook AR, et al: Trends in neonatal morbidity and mortality for very low birthweight infants. Am J Obstet Gynecol 196: 147.e1-e8, 2007.

2. Walsh MC, Szefler S, Davis J, Allen M, Van Marter L, Abman S, Blackmon L and Jobe A: Summary proceedings from the bronchopulmonary dysplasia group. Pediatrics 117 (Suppl 1): S52-S56, 2006.

3. Husain AN, Siddiqui NH and Stocker JT: Pathology of arrested acinar development in postsurfactant bronchopulmonary dysplasia. Hum Pathol 29: 710-717, 1998.

4. Wang Y, Huang C, Reddy Chintagari N, Bhaskaran M, Weng T, Guo Y, Xiao X and Liu L: miR-375 regulates rat alveolar epithelial cell trans-differentiation by inhibiting Wnt/ $\beta$-catenin pathway. Nucleic Acids Res 41: 3833-3844, 2013.

5. Bitterman PB, Polunovsky VA and Ingbar DH: Repair after acute lung injury. Chest 105 (Suppl 3): 118S-121S, 1994. 
6. Yang H, Fu J, Xue X, Yao L, Qiao L, Hou A, Jin L and Xing Y: Epithelial-mesenchymal transitions in bronchopulmonary dysplasia of newborn rats. Pediatr Pulmonol 49: 1112-1123, 2014.

7. Inoue $\mathrm{K}$, Shiga $\mathrm{T}$ and Ito $\mathrm{Y}$ : Run $\mathrm{x}$ transcription factors in neuronal development. Neural Dev 3: 20, 2008.

8. Ito Y: RUNX genes in development and cancer: regulation of viral gene expression and the discovery of RUNX family genes. Adv Cancer Res 99: 33-76, 2008.

9. Lee JM, Kwon HJ, Lai WF and Jung HS: Requirement of Runx3 in pulmonary vasculogenesis. Cell Tissue Res 356: 445-449, 2014

10. Liu Z, Chen L, Zhang X, Xu X, Xing H, Zhang Y, Li W, Yu H, Zeng $J$ and Jia J: RUNX3 regulates vimentin expression via miR-30a during epithelial-mesenchymal transition in gastric cancer cells. J Cell Mol Med 18: 610-623, 2014.

11. Mei PJ, Bai J, Liu H, Li C, Wu YP, Yu ZQ and Zheng JN RUNX3 expression is lost in glioma and its restoration causes drastic suppression of tumor invasion and migration. J Cancer Res Clin Oncol 137: 1823-1830, 2011.

12. Lee YS, Lee JW, Jang JW, Chi XZ, Kim JH, Li YH, Kim MK, $\mathrm{Kim}$ DM, Choi BS, Kim EG, et al: Runx3 inactivation is a crucial early event in the development of lung adenocarcinoma. Cancer Cell 24: 603-616, 2013.

13. Nishina S, Shiraha H, Nakanishi Y, Tanaka S, Matsubara M, Takaoka N, Uemura M, Horiguchi S, Kataoka J, Iwamuro M, et al: Restored expression of the tumor suppressor gene RUNX3 reduces cancer stem cells in hepatocellular carcinoma by suppressing Jagged1-Notch signaling. Oncol Rep 26: 523-531, 2011.

14. Levanon D, Brenner O, Negreanu V, Bettoun D, Woolf E, Eilam R, Lotem J, Gat U, Otto F, Speck N, et al: Spatial and temporal expression pattern of Runx3 (Aml2) and Runx1 (Aml1) indicates non-redundant functions during mouse embryogenesis. Mech Dev 109: 413-417, 2001.

15. Lee KS, Lee YS, Lee JM, Ito K, Cinghu S, Kim JH, Jang JW, $\mathrm{Li}$ YH, Goh YM, Chi XZ, et al: Runx3 is required for the differentiation of lung epithelial cells and suppression of lung cancer. Oncogene 29: 3349-3361, 2010.

16. Lee JM, Shin JO, Cho KW, Hosoya A, Cho SW, Lee YS, Ryoo HM, Bae SC and Jung HS: Runx3 is a crucial regulator of alveolar differentiation and lung tumorigenesis in mice. Differentiation 81: 261-268, 2011.

17. You K, Xu X, Fu J, Xu S, Yue X, Yu Z and Xue X: Hyperoxia disrupts pulmonary epithelial barrier in newborn rats via the deterioration of occludin and ZO-1. Respir Res 13: 36, 2012.

18. Willis BC, Liebler JM, Luby-Phelps K, Nicholson AG, Crandall ED, du Bois RM and Borok Z: Induction of epithelial-mesenchymal transition in alveolar epithelial cells by transforming growth factor-beta1: potential role in idiopathic pulmonary fibrosis. Am J Pathol 166: 1321-1332, 2005.

19. Cooney TP and Thurlbeck WM: The radial alveolar count method of Emery and Mithal: a reappraisal 1 - postnatal lung growth. Thorax 37: 572-579, 1982

20. Emanuel RL, Torday JS, Mu Q, Asokananthan N, Sikorski KA and Sunday ME: Bombesin-like peptides and receptors in normal fetal baboon lung: roles in lung growth and maturation. Am J Physiol 277: L1003-L1017, 1999.

21. Cullen A, Van Marter LJ, Allred EN, Moore M, Parad RB and Sunday ME: Urine bombesin-like peptide elevation precedes clinical evidence of bronchopulmonary dysplasia. Am J Respir Crit Care Med 165: 1093-1097, 2002.

22. Ito Y: Oncogenic potential of the RUNX gene family: 'overview'. Oncogene 23: 4198-4208, 2004.

23. Speck NA and Gilliland DG: Core-binding factors in haematopoiesis and leukaemia. Nat Rev Cancer 2: 502-513, 2002.

24. Mundlos S, Otto F, Mundlos C, Mulliken JB, Aylsworth AS, Albright S, Lindhout D, Cole WG, Henn W, Knoll JH, et al: Mutations involving the transcription factor CBFA1 cause cleidocranial dysplasia. Cell 89: 773-779, 1997.

25. Thomas DM, Johnson SA, Sims NA, Trivett MK, Slavin JL, Rubin BP, Waring P, McArthur GA, Walkley CR Holloway AJ, et al: Terminal osteoblast differentiation, mediated by runx 2 and $\mathrm{p} 27^{\mathrm{KIP} 1}$, is disrupted in osteosarcoma. J Cell Biol 167: 925-934, 2004

26. Bae SC and Choi JK: Tumor suppressor activity of RUNX3. Oncogene 23: 4336-4340, 2004.

27. Kato N, Tamura G, Fukase M, Shibuya H and Motoyama T: Hypermethylation of the RUNX3 gene promotor in testicular yolk sac tumor of infants. Am J Pathol 163: 387-391, 2003.

28. Bone KR, Gruper Y, Goldenberg D, Levanon D and Groner Y: Translation regulation of Runx3. Blood Cells Mol Dis 45: 112-116, 2010.
29. Tanaka S, Shiraha H, Nakanishi Y, Nishina S, Matsubara M, Horiguchi S, Takaoka N, Iwamuro M, Kataoka J, Kuwaki K, et al: Runt-related transcription factor 3 reverses epithelial-mesenchymal transition in hepatocellular carcinoma. Int J Cancer 131: 2537-2546, 2012.

30. Thomson S, Petti F, Sujka-Kwok I, Mercado P, Bean J, Monaghan M, Seymour SL, Argast GM, Epstein DM and Haley JD: A systems view of epithelial-mesenchymal transition signaling states. Clin Exp Metastasis 28: 137-155, 2011.

31. Lemieux E, Bergeron S, Durand V, Asselin C, Saucier C and Rivard N: Constitutively active MEK1 is sufficient to induce epithelial-to-mesenchymal transition in intestinal epithelial cells and to promote tumor invasion and metastasis. Int J Cancer 125: $1575-1586,2009$

32. Gheldof A and Berx G: Cadherins and epithelial-to-mesenchymal transition. Prog Mol Biol Transl Sci 116: 317-336, 2013.

33. Zhou B, Buckley ST, Patel V, Liu Y, Luo J, Krishnaveni MS, Ivan M, DeMaio L, Kim KJ, Ehrhardt C, et al: Troglitazone attenuates TGF- $\beta 1$-induced EMT in alveolar epithelial cells via a PPAR $\gamma$-independent mechanism. PLoS One 7: e38827, 2012.

34. Kojima T, Takano K, Yamamoto T, Murata M, Son S, Imamura M, Yamaguchi H, Osanai M, Chiba H, Himi T, et al: Transforming growth factor-beta induces epithelial to mesenchymal transition by down-regulation of claudin-1 expression and the fence function in adult rat hepatocytes. Liver Int 28: 534-545, 2008

35. Nakanishi H, Sugiura T, Streisand JB, Lonning SM and Roberts JD Jr: TGF-beta-neutralizing antibodies improve pulmonary alveologenesis and vasculogenesis in the injured newborn lung. Am J Physiol Lung Cell Mol Physiol 293: L151-L161, 2007.

36. Vicencio AG, Lee CG, Cho SJ, Eickelberg O, Chuu Y, Haddad GG and Elias JA: Conditional overexpression of bioactive transforming growth factor-beta1 in neonatal mouse lung: a new model for bronchopulmonary dysplasia? Am J Respir Cell Mol Biol 31: 650-656, 2004.

37. Fan JM, Ng YY, Hill PA, Nikolic-Paterson DJ, Mu W, Atkins RC and Lan HY: Transforming growth factor-beta regulates tubular epithelial-myofibroblast transdifferentiation in vitro. Kidney Int 56: 1455-1467, 1999.

38. Ng YY, Huang TP, Yang WC, Chen ZP, Yang AH, Mu W, Nikolic-Paterson DJ, Atkins RC and Lan HY: Tubular epithelial-myofibroblast transdifferentiation in progressive tubulointerstitial fibrosis in 5/6 nephrectomized rats. Kidney Int 54: 864-876, 1998.

39. Joss-Moore L, Carroll T, Yang Y, Fitzhugh M, Metcalfe D, Oman J, Hale M, Dong L, Wang ZM, Yu X, et al: Intrauterine growth restriction transiently delays alveolar formation and disrupts retinoic acid receptor expression in the lung of female rat pups. Pediatr Res 73: 612-620, 2013.

40. Subramaniam M, Bausch C, Twomey A, Andreeva S, Yoder BA, Chang L, Crapo JD, Pierce RA, Cuttitta F and Sunday ME: Bombesin-like peptides modulate alveolarization and angiogenesis in bronchopulmonary dysplasia. Am J Respir Crit Care Med 176: 902-912, 2007.

41. Jiang Y, Tong D, Lou G, Zhang Y and Geng J: Expression of RUNX3 gene, methylation status and clinicopathological significance in breast cancer and breast cancer cell lines. Pathobiology 75: 244-251, 2008.

42. Lee TI, Jenner RG, Boyer LA, Guenther MG, Levine SS, Kumar RM, Chevalier B, Johnstone SE, Cole MF, Isono K, et al: Control of developmental regulators by Polycomb in human embryonic stem cells. Cell 125: 301-313, 2006.

43. Lai KW, Koh KX, Loh M, Tada K, Subramaniam MM, Lim XY, Vaithilingam A, Salto-Tellez M, Iacopetta B, Ito Y, et al; Singapore Gastric Cancer Consortium: MicroRNA-130b regulates the tumour suppressor RUNX3 in gastric cancer. Eur J Cancer 46: 1456-1463, 2010.

44. Ito K, Liu Q, Salto-Tellez M, Yano T, Tada K, Ida H, Huang C, Shah N, Inoue M, Rajnakova A, et al: RUNX3, a novel tumor suppressor, is frequently inactivated in gastric cancer by protein mislocalization. Cancer Res 65: 7743-7750, 2005.

45. Soong R, Shah N, Peh BK, Chong PY, Ng SS, Zeps N, Joseph D, Salto-Tellez M, Iacopetta B and Ito Y: The expression of RUNX3 in colorectal cancer is associated with disease stage and patient outcome. Br J Cancer 100: 676-679, 2009.

46. Yanada M, Yaoi T, Shimada J, Sakakura C, Nishimura M, Ito K, Terauchi K, Nishiyama K, Itoh K and Fushiki S: Frequent hemizygous deletion at $1 \mathrm{p} 36$ and hypermethylation downregulate RUNX3 expression in human lung cancer cell lines. Oncol Rep 14: 817-822, 2005. 